\title{
Effects of Climate Change on Marine Organisms
}

\author{
Daniel Assan1,2,3 (), Felix K. A. Kuebutornye1,3,4, Umar Farouk Mustapha1,2,3, Huapu Chen1,2,3, \\ Guangli Li1,2,3*
}

${ }^{1}$ Guangdong Research Center on Reproductive Control and Breeding Technology of Indigenous Valuable Fish Species, Zhanjiang, China

${ }^{2}$ Key Laboratory of Marine Ecology and Aquaculture Environment of Zhanjiang, Key Laboratory of Aquaculture in South China Sea for Aquatic Economic Animal of Guangdong Higher Education Institutes, Zhanjiang, China

${ }^{3}$ Fisheries College, Guangdong Ocean University, Zhanjiang, China

${ }^{4}$ Guangdong Provincial Engineering Laboratory for Mariculture Organism Breeding, Guangdong Provincial Key Laboratory of Pathogenic Biology and Epidemiology for Aquatic Economic Animals, Zhanjiang, China

Email: kobbyassan95@yahoo.com, *ligl@gdou.edu.cn

How to cite this paper: Assan, D., Kuebutornye, F. K. A., Mustapha, U. F., Chen, H. P., \& Li, G. L. (2020). Effects of Climate Change on Marine Organisms. American Journal of Climate Change, 9, 204-216. https://doi.org/10.4236/ajcc.2020.93013

Received: June 3, 2020

Accepted: September 1, 2020

Published: September 4, 2020

Copyright (c) 2020 by author(s) and Scientific Research Publishing Inc. This work is licensed under the Creative Commons Attribution International License (CC BY 4.0).

http://creativecommons.org/licenses/by/4.0/ (c) (i) Open Access

\begin{abstract}
Global warming has become a global challenge having dire consequences on different aspects of the environment due to the melting of glaciers, excess carbon dioxide $\left(\mathrm{CO}_{2}\right)$, and excess warming of water bodies among others. At a faster pace recently, climate change is affecting the marine environment, causing numerous alterations. Here, we address its consequences and the numerous alterations, which are more vital for researchers and global agencies to advocate more on why it's essential to lessen the impact of climate change. Our review showed that the impacts of climate change are articulated at several stages of the marine ecosystem where it affects the inhabitants and their habitats. In response to climate change (ocean warming) marine species shift their latitudinal range to find suitable conditions leading to the redistribution of species. In addition, we found that growth reduction, sub-optimal behaviors, and reduced immune-competence of marine organisms, are as a result of thermal stress due to climate change. Also, the periodic changes in temperature above or below the optimum have a meditative reproductive effect on marine species, including fish. Finally, we discovered that due to higher water temperatures, several diseases showcase greater virulence in the sense that the marine species become less resistant to these diseases due to stress, increased virulence stimuli, or increased transmission.
\end{abstract}

\section{Keywords}

Aquatic, Climate Change, Fisheries, Marine Organisms, Physiology 


\section{Introduction}

Climate change is anticipated to affect organisms including their individualism, the scope and structure of their populations, the species construction of communities, and the structure as well as the functioning of ecosystems. Effects include poleward or high-altitude shifts in the distribution of ectothermic animals (Spies et al., 2020). All aquatic ecosystems, comprising of freshwater bodies, coastal estuarine habitats as well as marine ecosystems are influenced by climate change (Beck, 2018; Hewitt et al., 2016). According to previous studies, relatively small changes in temperature modifies the metabolism and physiology of aquatic animals, such as fish, resulting in difficulties in growth, fecundity, feeding behavior, distribution, migration as well as abundance (Mir et al., 2019; Nagelkerken \& Munday, 2016; Pörtner et al., 2017; Rael et al., 2020). However, the impacts of climate change have been revised and shortened for freshwater and marine ecosystems (Hewitt et al., 2016; Rosenzweig et al., 2007). Climate change has led to the adjustments in the distribution of invertebrates, vertebrates, and also plant species, in terms of the timing of their cyclic activities and their physiological responses in both aquatic and terrestrial environs (Beaugrand \& Kirby, 2018; Gilg et al., 2017; Root et al., 2003; Rosenzweig et al., 2007; Sunday et al., 2015), these include marine zooplankton and fish (Beaugrand \& Kirby, 2018; Spies et al., 2020). According to literature and recent analyses, threats are imminent and predictions are being made on climate warming in the next decades (Smith et al., 2007). Esia-Donkoh (2017) specified that an increase in temperature of $2^{\circ} \mathrm{C}$ to $3^{\circ} \mathrm{C}$ above pre-industrial levels is expected to place predictably $30 \%$ of plants and animal species at high risk of extinction, while key changes in the structure and function of marine and extra aquatic ecosystems are foreseen, and in current eras, these changes are taking place and if precautions are not put in place they will intensify, triggering more species to go extinct.

Global climate change, which is extensively driven by anthropogenic activities, referencing to (Hewitt et al., 2016), has become an awful reality in the past century and its impact is expected to increase in the future. Also, recent models have projected a $0.2^{\circ} \mathrm{C}$ increase in the mean worldwide temperature per decade in the next 2 decades and $1.8^{\circ} \mathrm{C}-4^{\circ} \mathrm{C}$ increase by the year 2100 . According to (Poloczanska et al., 2016), aquatic ecosystems are prone to the effects of climate change globally. This is because, the vast majority $(>95 \%)$ of aquatic species are ectotherms, in other words, poikilothermic. Temperature is very keen on the physiology of poikilotherms, as their body temperature changes with that of the environment, resulting in the adjustments of the rates of all physiological and biochemical reactions and steadiness of biological molecules (Bonachea, 2019; Heuer et al., 2019). Paleontological records, as well as history on global warming, demonstrates that even the modest changes in environmental temperature by a few degrees centigrade results in major shifts in ectothermic distributions and mass extinction of their population (Gómez et al., 2008; Heuer et al., 2019). Marine ecosystems are very momentous in the regulation of the climate and are very subtle to climate change (Hoegh-Guldberg et al., 2014; Hoegh-Guldberg \& 
Bruno, 2010). The effects of climate change on marine organisms differ in terms of latitude, territory, water column features, riverine structures, and flow systems. However, some universal outlooks of climatic change are possible phaseshifting of periodic temperature profiles, eminent seasonal maxima, and minima as well as a sign of an increase in atmospheric $\mathrm{CO}_{2}$, which turns to increase ocean acidification (Lough \& Hobday, 2011).

Quite a lot of recent studies focused on the assessment of the ecological status of marine waters in an integrative means (Borja et al., 2011; Commission, 2010), but it is still not clear how marine ecosystems react to human actions and climate change (Borja et al., 2013). Studies on climate change effects in aquatic ecosystems are still far behind studies related to land-dwelling ecosystems (Richardson \& Poloczanska, 2008). This is primarily due to the aspect complexity and variability of seas and the lack of long time series of data of relevant variables (Pratchett et al., 2011). Moreover, many studies focused on specific marine ecosystems or their specific components, such as coral reefs (Gilg et al., 2017; Munday, 2004; Pandolfi et al., 2011), seagrasses (Björk et al., 2008; Jordà et al., 2013; Koch et al., 2013), or fishes (Koehn et al., 2011; Mir et al., 2019; Munday et al., 2009) without focusing on most of the important parts, including the marine ecosystem as a whole. This implies that there is a need for more research into climate change and its effect on the marine world. Nonetheless, here, we address its consequences and the numerous alterations, which are more vital for researchers and global agencies to advocate more on why it's essential to lessen the impact of climate change.

\section{Climate Change Impacts}

\subsection{Effects of Climate Change on Species Distribution and Abundance of Marine Organisms}

Climate change is well-thought-out in determining the past and future distributions of biodiversity (Peterson et al., 2002; Root et al., 2003; Sunday et al., 2015). Impacts of climate change are articulated at several stages. The most proximate effects of climate change are in the phenology of species (Lynch et al., 2016; Ruiz-Navarro et al., 2016). Climate change may affect the distribution and the abundance of organisms in their ecosystem (Marcogliese, 2016; O'connor et al., 2015; Potts et al., 2014; White, 2018) and according to (Worm et al., 2005), the arrays and trends in species diversity in the open oceans remain puzzling. There is a strong bond between the array of marine species richness and environmental factors, remarkably for fish and invertebrates (Chaudhary et al., 2016). Also, observations and theories advocate that marine species respond to ocean warming by shifting their latitudinal range (Kleisner et al., 2016; Mueter \& Litzow, 2008; Spies et al., 2020; Sunday et al., 2015) and depth range (Dulvy et al., 2008). The responses of such species may lead to local elimination and raids, resulting in changes in the array of marine species richness (Kleisner et al., 2016). Marine organisms averagely have lengthened the leading edges of their distributions by 
$72.0 \pm 13.5 \mathrm{~km}$ per decade (generally polewards), while marine phenology in spring has progressed by $4.4 \pm 1.1$ days decade (Poloczanska et al., 2013).

There is an increasing problem of climate change for marine fisheries; some of the tropical fish species face regional extermination problems. Some of the other species may migrate towards higher latitudes. Coastal areas are more likely to be obstructed through the increasing sea surface temperature, sea-level rise, extremes of nutrient enrichment (eutrophication), and invasive species. Even a disparity of $10^{\circ} \mathrm{C}$ temperature in seawater may affect the assortment, distribution, and life cycle of marine species (Neelmani et al., 2019). Reduced oxygen solubility thus, reducing dissolved oxygen (DO) concentrations at which permeation occurs could be a result of the surges in water temperature whiles most marine species and ecosystems are currently under several concurrent threats (Johan et al., 2015; Lõhmus \& Björklund, 2015).

Phytoplanktons have conflicting sensitivities to $\mathrm{CO}_{2}$ concentration and have a variety of mechanisms for the utilization of carbon. Thus, the increase in seawater $\mathrm{CO}_{2}$ concentration will not only change the activity of individual phytoplankton species but will also tend to favor some species over others. These shifts in phytoplankton's ecological structure will impact the community structure of the higher trophic levels that are dependent on phytoplankton as food and will also affect the cycling of elements that diverge between species (e.g. carbonate by calcifying organisms and silicate by non-calcifying organisms) (Domingues et al., 2017).

Fishery ecosystems and fishing-based livelihoods are subject to a range of climate-related variability, from extreme weather events, floods, and droughts, through changes in the marine ecosystem, productivity and changing patterns and the abundance of fish stocks (Neelmani et al., 2019). The distribution and migration of oceanic tuna, which are influenced by the thermocline, may be strongly prejudiced (Kingma, 2018; Zacharia, 2017). There are difficulties in projecting how populations will behave under extremely different conditions, and under these conditions, fish stock assessment, which is already difficult may prove dreadful (Kingma, 2018). Fisheries management will likely become far more antagonistic because the abundance of fish (fin and shell) populations and the composition of communities will change in unanticipated ways (Vivekanandan, 2006). Figure 1 shows how climate change is expected to impact marine fisheries. This expected climate change impact goes along way to affect fishermen, interms of catchline decline, their rehabilitation into inland areas, as well as economic drain (Vivekanandan, 2006).

\subsection{Effects of Climate Change on Growth and Reproduction of Marine Organisms}

Globally, near-shore marine territories are increasingly being exposed to a variety of anthropogenic stressors, such as sedimentation, eutrophication, and pollution (Morgan \& Kench, 2016), which leads or links with climate change, and of which all have insightful impacts on reproduction, recruitment, and survival of larvae. Increased temperature as a result of climate change may lead to 
thermal stress in aquatic animals, causing growth reduction, sub-optimal behaviors, and reduced immune-competence (Mir et al., 2019; Nagelkerken \& Munday, 2016; Rael et al., 2020; Van Woesik \& Randall, 2017). The aftermaths of climate change are not solely limited to effects of temperature on hosts and their parasites, but also include the modifications in water levels and flow systems, eutrophication, stratification, changes in acidification, condensed ice cover, fluctuations in ocean currents, increased ultra-violet (UV) light penetration, runoff, weather extremes, in which one way or the other are linked or are as a result of climate change. All these features will have significance on entire ecosystems and their food webs (Marcogliese, 2016; White, 2018). Periodical change in temperature has a meditative effect on reproduction on fish; increasing temperatures signal reproductive development in spring-spawning species, and dwindling temperatures stimulate reproduction in autumn spawners. Eminent temperatures shorten spring spawning and interpose autumn spawning (Marcogliese, 2016). Reproduction will be affected when temperature rises, but the nature of these effects will pivot on the period and breadth of the increase and variety from segment shifting of spawning to wide-ranging inhibition of reproduction (Pankhurst \& Munday, 2011). Temperature is an indispensable physical supervisory factor in the lives of aquatic animals (e.g. fish) and this effect is showcased predominantly strong in control of all reproductive progress from gamete development and ripening, ovulation and spermiation, spawning, embryogenesis, and hatching, to larval and to the developmental and survival stage of juvenile (Pankhurst, 2016; Pankhurst \& Munday, 2011).

Temperature is generally well-organized to be a minor prompt to photoperiod in seasonal reproductive phases in sexually matured adults, but it has an impact on coordinating the final stages of reproductive maturity, and also in shortening reproductive chapters (Pankhurst, 2016). Fish larvae are usually greatly delicate than adults to environmental discrepancies and turn to be particularly defenseless to climate change. Although temperature has direct effects on the embryonic extent and egg survival, it also affects size at hatching, the developmental rate, pelagic larval duration, and survival of aquatic animals (Pankhurst, 2016; Pankhurst \& Munday, 2011). Preeminent $\mathrm{CO}_{2}$ also has more wide-ranging detrimental effects on the survival, growth, and respiratory physiology of aquatic or marine animals (Lee et al., 2016; Pörtner et al., 2017; Hans-Otto Pörtner et al., 2014; Smith, 2016).

According to (Verberk \& Bilton, 2011), the significance of physiological effects in a climate change framework at the ecosystem level has only been verified for the perception of "oxygen and capacity dependent thermal tolerance (OCLTT)" in animals. This implies that more research should be done on broader bases to know how climate change affects aquatic animals. According to (Pedersen et al., 2016), while the pursuit of mechanistic relations between climate and plankton lingers, the impact of weather on the concentration of ocean mixing is likely to be crucial to the linkage. As a result, this concentration affects light levels, surface temperatures and the extent of how nutrient is reutilized from deep layers, thus, impelling the growth of phytoplankton, and thus driving bottom-up pro- 
cesses (i.e. the role of members of one trophic level as food items for higher trophic levels) throughout the pelagic food chain.

Temperature is known to be the highly prevalent climate-correlated influence on biological function (Johnston \& Bennett, 2008). In the same way, growth is temperature-dependent and in the preliminary levels of warming, the altering temperature may lead to a change in community size structure as well as biomass (Wiedenmann et al., 2008). Warming, however, will not necessarily increase growth rates (Pratchett et al., 2008). Reproduction and reproductive output timings, as well as the condition of juveniles and larvae, are also subject to inconsistency (Pratchett et al., 2008). Juveniles of marine organisms, specifically marine animals can be particularly inclined to temperature, salinity, and $\mathrm{pH}$ changes, and larvae may accede to preeminent temperatures that their adult stages can live on (Flynn \& Todgham, 2018; McLeod et al., 2015). Hatching times of eggs may affect the chances of larvae to survive if larval appearance does not concur with food availability. Changes in the timings of plankton blooms (Platt et al., 2003), as well as temperature-driven phenological changes (Edwards \& Richardson, 2004), may lead to breaks in food chains (Hipfner, 2008; Pedersen et al., 2016). Pelagic and marine intertidal organisms also show complex physiological responses to temperature stress, with likely undesirable effects on growth and maturity, which lead to changes in population dynamics and ecosystem processes (Yao \& Somero, 2014). Outside this range, however, adaptation fails and the chance of mortality increases, whereas growth and development reduce, and populations decline or are driven to local extinction. Key biological processes can also be prejudiced by the dissimilarities in temperatures (Hoegh-Guldberg et al., 2014; Hoegh-Guldberg \& Bruno, 2010; Poloczanska et al., 2016) such as reproduction and growth. Most fish species have a constricted range of ideal temperatures for their growth, development for their basic metabolism, and availability of food organisms (Neelmani et al., 2019).

\subsection{Effects of Climate Change on Disease Outbreak on Marine Organisms}

Diseases and parasites can have a severe influence on the entire ecosystem, including its organisms (plants, animals and microorganisms). According to (Johan et al., 2015; Marcogliese, 2016; Van Woesik \& Randall, 2017; White, 2018), climate change will have a profound influence on the spread of parasites and diseases in aquatic ecosystems. Several diseases showcase greater virulence at higher temperatures and this may be the outcome of reduced resistance due to stress, increased virulence stimuli, or increased transmission (Glynn et al., 2015; Van Woesik \& Randall, 2017). Climate change will not only affect the species of parasites directly but also through the distribution changes and the abundance of the hosts (Marcogliese, 2016; O'connor et al., 2015; Potts et al., 2014). The response to increasing temperatures on the side of parasites may be sturdier as compared to their hosts (Blasco-Costa et al., 2015). The occurrence of diseases is directly linked to variations in the ecosystem of hosts or pathogens, or both (Jo- 
han et al., 2015; Lõhmus \& Björklund, 2015). The most apparent effects are likely to result from the extension of the geographical range of pathogens (Van Woesik \& Randall, 2017). Although not all diseases in the ocean are linked to climate change alone, it discloses to increase in corals, sea urchins, mollusks, sea turtles, and marine mammals (Lafferty et al., 2004).

The diseases of aquatic organisms with the strongest links to climate are those of marine invertebrates, including mollusks, echinoderms and cnidarians. Mass mortality associated with high temperatures has been documented in shrimps, seagrasses, oysters, starfish, corals, abalone, and sea urchins (Johan et al., 2015; Lõhmus \& Björklund, 2015). The populations affected are key constituents in marine habitats, where the effects of disease cascade throughout the local ecosystem, affecting entire communities of organisms, as well as any commercial activities dependent on these natural resources (Bruno et al., 2007; Johan et al., 2015; Lõhmus \& Björklund, 2015).

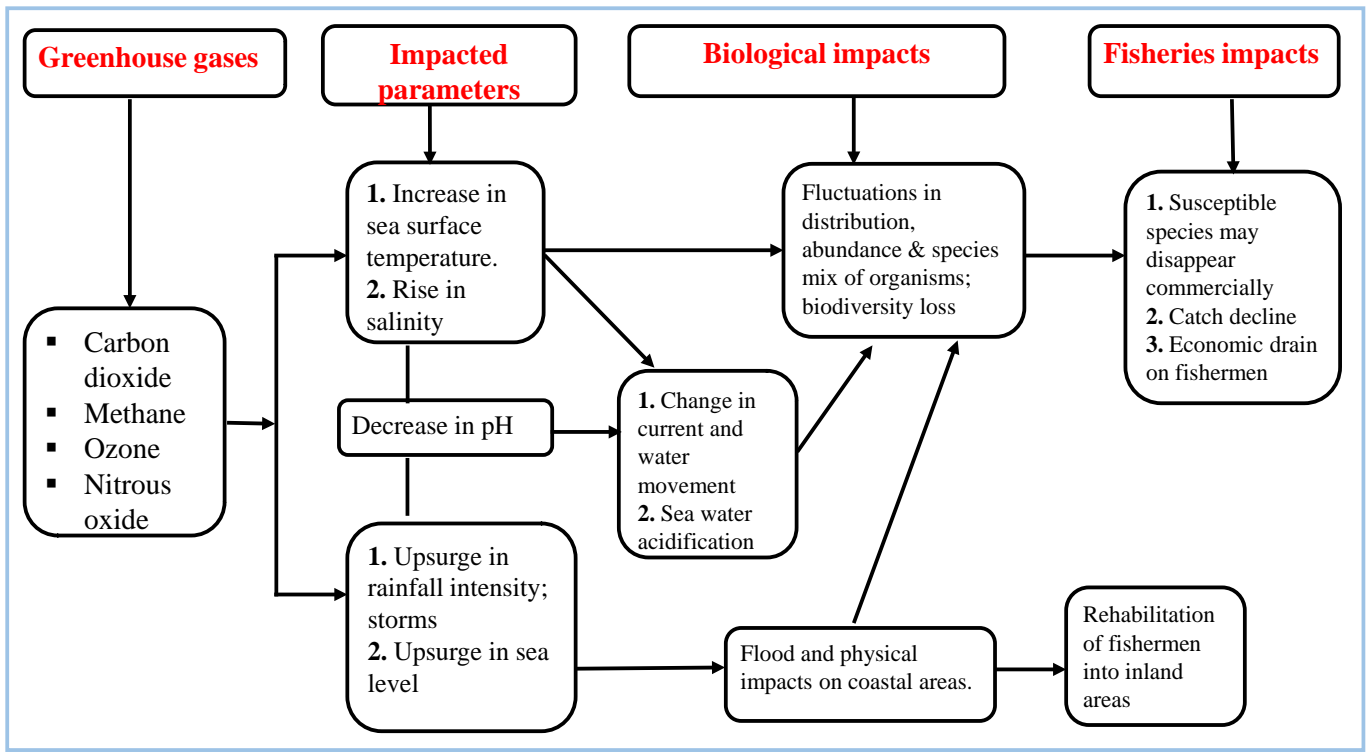

Figure 1. Expected impact of climate change on marine fisheries, revised from (Vivekanandan, 2006).

\section{Conclusion}

Anthropogenic activities being the main course of climate change, it is now up to us humans to make it a priority to control and reduce its effect on nature as a whole. Climate change will, or is already, affecting reproductive and early life history events of most organisms (both marine and terrestrial), especially fish. Temperature is said to be one of the most fundamental variables affecting the lives of fishes, but we still know discouragingly little about its effects. The rate at which the climate is changing coupled with global warming, instant preventive, or control measures is necessary to prevent future consequences to nature, especially to marine and terrestrial ecosystems alongside their organisms, which are of most beneficial to humans. As it may be from rising sea levels, warming waters, or melting glaciers and permafrost, the impact of climate change is set to 
have drastic effects on aquatic and terrestrial organisms (invertebrates, vertebrates, and mammals) which live within and or around the affected areas.

To some extent, the impacts of climate change cannot be avoided over the next few years or decades. The consequences will become more severe the longer it takes policymakers to find solutions to reduce it. Global organizations such as the UN among others should use their worldwide platforms to educate people on climate change and impacts as well as how to prevent or reduce it. Further studies should be conducted to quantify the impacts of climate change on marine, as well as freshwater quality parameters and also impacts of climate change on freshwater organisms specifically. More research should be carried out to determine the impacts of climate change on the marine ecosystem as a whole since there isn't enough as compared to that of the terrestrial ecosystem. Additional studies should be conducted on the effects of climate change on the development of marine aquatic species and their interaction with pollutants.

\section{Conflicts of Interest}

The authors declare no conflicts of interest.

\section{References}

Beaugrand, G., \& Kirby, R. R. (2018). How Do Marine Pelagic Species Respond to Climate Change? Theories and Observations. Annual Review of Marine Science, 10, 169197. https://doi.org/10.1146/annurev-marine-121916-063304

Beck, K. (2018). Direct and Indirect Effects of Long-Term Climatic Change on Terrestrial-Aquatic Ecosystem Interaction in Tasmania.

Björk, M., Short, F., Mcleod, E., \& Beer, S. (2008). Managing Seagrasses for Resilience to Climate Change. IUCN.

Blasco-Costa, I., Rouco, C., \& Poulin, R. (2015). Biogeography of Parasitism in Freshwater Fish: Spatial Patterns in Hot Spots of Infection. Ecography, 38, 301-310.

https://doi.org/10.1111/ecog.01020

Bonachea, L. A. (2019). A Low-Cost Laboratory Demonstration of the Effects of Temperature on the Metabolism of an Aquatic Poikilotherm. Journal of Biological Education, 1-6. https://doi.org/10.1080/00219266.2019.1643763

Borja, A., Elliott, M., Andersen, J. H., Cardoso, A. C., Carstensen, J., Ferreira, J. G. et al. (2013). Good Environmental Status of Marine Ecosystems: What Is It and How Do We Know When We Have Attained It? Marine Pollution Bulletin, 76, 16-27. https://doi.org/10.1016/j.marpolbul.2013.08.042

Borja, Á., Galparsoro, I., Irigoien, X., Iriondo, A., Menchaca, I., Muxika, I. et al.(2011). Implementation of the European Marine Strategy Framework Directive: A Methodological Approach for the Assessment of Environmental Status, from the Basque Country (Bay of Biscay). Marine Pollution Bulletin, 62, 889-904.

https://doi.org/10.1016/j.marpolbul.2011.03.031

Bruno, J. F., Selig, E. R., Casey, K. S., Page, C. A., Willis, B. L., Harvell, C. D. et al. (2007). Thermal Stress and Coral Cover as Drivers of Coral Disease Outbreaks. PLoS Biology, 5, e124. https://doi.org/10.1371/journal.pbio.0050124

Chaudhary, C., Saeedi, H., \& Costello, M. J. (2016). Bimodality of Latitudinal Gradients in Marine Species Richness. Trends in Ecology \& Evolution, 31, 670-676. 
https://doi.org/10.1016/j.tree.2016.06.001

Commission, H. (2010). Ecosystem Health of the Baltic Sea 2003-2007: HELCOM Initial Holistic Assessment. Baltic Sea Environment Proceedings, 122, 63.

Domingues, R. B., Guerra, C. C., Galvão, H. M., Brotas, V., \& Barbosa, A. B. (2017). Short-Term Interactive Effects of Ultraviolet Radiation, Carbon Dioxide and Nutrient Enrichment on Phytoplankton in a Shallow Coastal Lagoon. Aquatic Ecology, 51, 91-105. https://doi.org/10.1007/s10452-016-9601-4

Dulvy, N. K., Rogers, S. I., Jennings, S., Stelzenmüller, V., Dye, S. R., \& Skjoldal, H. R. (2008). Climate Change and Deepening of the North Sea Fish Assemblage: A Biotic Indicator of Warming Seas. Journal of Applied Ecology, 45, 1029-1039.

https://doi.org/10.1111/j.1365-2664.2008.01488.x

Edwards, M., \& Richardson, A. J. (2004). Impact of Climate Change on Marine Pelagic Phenology and Trophic Mismatch. Nature, 430, 881. https://doi.org/10.1038/nature02808

Esia-Donkoh, K. (2017). Fishing Communities' Adaptation to Climate Change At-Komenda-Edina-Eguafo-Abrem Municipality, Ghana.

Flynn, E. E., \& Todgham, A. E. (2018). Thermal Windows and Metabolic Performance Curves in a Developing Antarctic Fish. Journal of Comparative Physiology B, 188, 271-282. https://doi.org/10.1007/s00360-017-1124-3

Gilg, O., Kovacs, K. M., Aars, J., Fort, J., Gauthier, G., Grémillet, D. et al. (2017). Climate Change and the Ecology and Evolution of Arctic Vertebrates. Annals of the New York Academy of Sciences, 1249, 166-190.

Glynn, P. W., Riegl, B., Purkis, S., Kerr, J. M., \& Smith, T. B. (2015). Coral Reef Recovery in the Galápagos Islands: The Northernmost Islands (Darwin and Wenman). Coral Reefs, 34, 421-436. https://doi.org/10.1007/s00338-015-1280-4

Gómez, J. J., Goy, A., \& Canales, M. L. (2008). Seawater Temperature and Carbon Isotope Variations in Belemnites Linked to Mass Extinction during the Toarcian (Early Jurassic) in Central and Northern Spain. Comparison with Other European Sections. Palaeogeography, Palaeoclimatology, Palaeoecology, 258, 28-58. https://doi.org/10.1016/j.palaeo.2007.11.005

Heuer, R. M., Stieglitz, J. D., Enochs, I. C., Pasparakis, C. M., Benetti, D. D., \& Grosell, M. (2019). Effects of Temperature on Athletic Performance in the Pelagic Mahi-Mahi (Coryphaena hippurus). The FASEB Journal, 33, 723-726.

Hewitt, J. E., Ellis, J. I., \& Thrush, S. F. (2016). Multiple Stressors, Nonlinear Effects and the Implications of Climate Change Impacts on Marine Coastal Ecosystems. Global Change Biology, 22, 2665-2675. https://doi.org/10.1111/gcb.13176

Hipfner, J. M. (2008). Matches and Mismatches: Ocean Climate, Prey Phenology and Breeding Success in a Zooplanktivorous Seabird. Marine Ecology Progress Series, 368, 295-304. https://doi.org/10.3354/meps07603

Hoegh-Guldberg, O., \& Bruno, J. F. (2010). The Impact of Climate Change on the World's Marine Ecosystems. Science, 328, 1523-1528. https://doi.org/10.1126/science.1189930

Hoegh-Guldberg, O., Cai, R., Poloczanska, E. S., Brewer, P. G., Sundby, S., Hilmi, K. et al. (2014). The Ocean.

Johan, O., Bengen, D. G., Zamani, N. P., \& Sweet, M. J. (2015). The Distribution and Abundance of Black Band Disease and White Syndrome in Kepulauan Seribu, Indonesia. HA YA TI Journal of Biosciences, 22, 105-112. https://doi.org/10.1016/j.hjb.2015.09.001

Johnston, I. A., \& Bennett, A. F. (2008). Animals and Temperature: Phenotypic and Evolutionary Adaptation (Vol. 59). Cambridge: Cambridge University Press. 
Jordà, G., Marbà, N., \& Duarte, C. M. (2013). Climate Warming and Mediterranean Seagrass. Nature Climate Change, 3, 3. https://doi.org/10.1038/nclimate1766

Kingma, E. K. (2018). The Principle of Compatibility: Its Application within the World's Largest Tuna Fishery.

Kleisner, K. M., Fogarty, M. J., McGee, S., Barnett, A., Fratantoni, P., Greene, J. et al. (2016). The Effects of Sub-Regional Climate Velocity on the Distribution and Spatial Extent of Marine Species Assemblages. PLOS ONE, 11, e0149220. https://doi.org/10.1371/journal.pone.0149220

Koch, M., Bowes, G., Ross, C., \& Zhang, X. (2013). Climate Change and Ocean Acidification Effects on Seagrasses and Marine Macroalgae. Global Change Biology, 19, 103-132. https://doi.org/10.1111/j.1365-2486.2012.02791.x

Koehn, J. D., Hobday, A. J., Pratchett, M. S., \& Gillanders, B. M. (2011). Climate Change and Australian Marine and Freshwater Environments, Fishes and Fisheries: Synthesis and Options for Adaptation. Marine and Freshwater Research, 62, 1148-1164. https://doi.org/10.1071/MF11139

Lafferty, K. D., Porter, J. W., \& Ford, S. E. (2004). Are Diseases Increasing in the Ocean? Annual Review of Ecology, Evolution, and Systematics, 35, 31-54. https://doi.org/10.1146/annurev.ecolsys.35.021103.105704

Lee, C., Hong, S., Kwon, B.-O., Lee, J.-H., Ryu, J., Park, Y.-G. et al. (2016). Lethal and Sub-Lethal Effects of Elevated $\mathrm{CO}_{2}$ Concentrations on Marine Benthic Invertebrates and Fish. Environmental Science and Pollution Research, 23, 14945-14956. https://doi.org/10.1007/s11356-016-6622-4

Lõhmus, M., \& Björklund, M. (2015). Climate Change: What Will It Do to Fish-Parasite Interactions? Biological Journal of the Linnean Society, 116, 397-411. https://doi.org/10.1111/bij.12584

Lough, J. M., \& Hobday, A. J. (2011). Observed Climate Change in Australian Marine and Freshwater Environments. Marine and Freshwater Research, 62, 984-999. https://doi.org/10.1071/MF10272

Lynch, A. J., Myers, B. J. E., Chu, C., Eby, L. A., Falke, J. A., Kovach, R. P. et al. (2016). Climate Change Effects on North American Inland Fish Populations and Assemblages. Fisheries, 41, 346-361. https://doi.org/10.1080/03632415.2016.1186016

Marcogliese, D. J. (2016). The Distribution and Abundance of Parasites in Aquatic EcoSystems in a Changing Climate: More than Just Temperature. Integrative and Comparative Biology, 56, 611-619. https://doi.org/10.1093/icb/icw036

McLeod, I. M., Jones, R. E., Jones, G. P., Takahashi, M., \& McCormick, M. I. (2015). Interannual Variation in the Larval Development of a Coral Reef Fish in Response to Temperature and Associated Environmental Factors. Marine Biology, 162, 2379-2389. https://doi.org/10.1007/s00227-015-2765-y

Mir, M. I., Siddiqui, U., \& Patiyal, R. S. (2019). Comparative Study of Metabolic Gene Regulation with Seasonal Fluctuation of Temperature in Rainbow Trout (Oncorhynchus mykiss) under Captive Conditions. Genetics of Aquatic Organisms, 3, 9-16. https://doi.org/10.4194/2459-1831-v3_1_02

Morgan, K. M., \& Kench, P. S. (2016). Parrotfish Erosion Underpins Reef Growth, Sand Talus Development and Island Building in the Maldives. Sedimentary Geology, 341, 50-57. https://doi.org/10.1016/j.sedgeo.2016.05.011

Mueter, F. J., \& Litzow, M. A. (2008). Sea Ice Retreat Alters the Biogeography of the Bering Sea Continental Shelf. Ecological Applications, 18, 309-320.

https://doi.org/10.1890/07-0564.1

Munday, P. L. (2004). Habitat Loss, Resource Specialization, and Extinction on Coral 
Reefs. Global Change Biology, 10, 1642-1647.

https://doi.org/10.1111/j.1365-2486.2004.00839.x

Munday, P. L., Dixson, D. L., Donelson, J. M., Jones, G. P., Pratchett, M. S., Devitsina, G. V. et al. (2009). Ocean Acidification Impairs Olfactory Discrimination and Homing Ability of a Marine Fish. Proceedings of the National Academy of Sciences, 106, 18481852. https://doi.org/10.1073/pnas.0809996106

Nagelkerken, I., \& Munday, P. L. (2016). Animal Behaviour Shapes the Ecological Effects of Ocean Acidification and Warming: Moving from Individual to Community-Level Responses. Global Change Biology, 22, 974-989. https://doi.org/10.1111/gcb.13167

Neelmani, R. C., Pal, M., Sarman, V., Vyas, U. D., \& Muniya, T. N. (2019). Impacts of Climate Change on Marine Biodiversity.

O'connor, M. I., Holding, J. M., Kappel, C. V, Duarte, C. M., Brander, K., Brown, C. J. et al. (2015). Strengthening Confidence in Climate Change Impact Science. Global Ecology and Biogeography, 24, 64-76. https://doi.org/10.1111/geb.12218

Pandolfi, J. M., Connolly, S. R., Marshall, D. J., \& Cohen, A. L. (2011). Projecting Coral Reef Futures under Global Warming and Ocean Acidification. Science, 333, 418-422. https://doi.org/10.1126/science.1204794

Pankhurst, N. W. (2016). Reproduction and Development. In Fish Physiology (Vol. 35, pp. 295-331). Amsterdam: Elsevier. https://doi.org/10.1016/B978-0-12-802728-8.00008-4

Pankhurst, N. W., \& Munday, P. L. (2011). Effects of Climate Change on Fish Reproduction and Early Life History Stages. Marine and Freshwater Research, 62, 1015-1026. https://doi.org/10.1071/MF10269

Pedersen, M. W., Kokkalis, A., Bardarson, H., Bonanomi, S., Boonstra, W. J., Butler, W. E. et al. (2016). Trends in Marine Climate Change Research in the Nordic Region since the First IPCC Report. Climatic Change, 134, 147-161. https://doi.org/10.1007/s10584-015-1536-6

Peterson, A. T., Ortega-Huerta, M. A., Bartley, J., Sánchez-Cordero, V., Soberón, J., Buddemeier, R. H. et al. (2002). Future Projections for Mexican Faunas under Global Climate Change Scenarios. Nature, 416, 626-629. https://doi.org/10.1038/416626a

Platt, T., Fuentes-Yaco, C., \& Frank, K. T. (2003). Marine Ecology: Spring Algal Bloom and Larval Fish Survival. Nature, 423, 398. https://doi.org/10.1038/423398b

Poloczanska, E. S., Brown, C. J., Sydeman, W. J., Kiessling, W., Schoeman, D. S., Moore, P. J. et al. (2013). Global Imprint of Climate Change on Marine Life. Nature Climate Change, 3, 919-925. https://doi.org/10.1038/nclimate1958

Poloczanska, E. S., Burrows, M. T., Brown, C. J., García Molinos, J., Halpern, B. S., HoeghGuldberg, O. et al. (2016). Responses of Marine Organisms to Climate Change across Oceans. Frontiers in Marine Science, 3, 62.

https://www.frontiersin.org/article/10.3389/fmars.2016.00062 https://doi.org/10.3389/fmars.2016.00062

Pörtner, Hans-O, Bock, C., \& Mark, F. C. (2017). Oxygen- and Capacity-Limited Thermal Tolerance: Bridging Ecology and Physiology. Journal of Experimental Biology, 220, 2685-2696. https://doi.org/10.1242/jeb.134585

Pörtner, Hans-Otto, Karl, D. M., Boyd, P. W., Cheung, W., Lluch-Cota, S. E. et al. (2014). Ocean Systems. In Climate Change 2014: Impacts, Adaptation, and Vulnerability. Part A: Global and Sectoral Aspects. Contribution of Working Group II to the Fifth Assessment Report of the Intergovernmental Panel on Climate Change (pp. 411-484). Cambridge: Cambridge University Press.

Potts, W. M., Henriques, R., Santos, C. V, Munnik, K., Ansorge, I., Dufois, F. et al. (2014). 
Ocean Warming, a Rapid Distributional Shift, and the Hybridization of a Coastal Fish Species. Global Change Biology, 20, 2765-2777. https://doi.org/10.1111/gcb.12612

Pratchett, M. S., Bay, L. K., Gehrke, P. C., Koehn, J. D., Osborne, K., Pressey, R. L. et al. (2011). Contribution of Climate Change to Degradation and Loss of Critical Fish Habitats in Australian Marine and Freshwater Environments. Marine and Freshwater Research, 62, 1062-1081. https://doi.org/10.1071/MF10303

Pratchett, M. S., Munday, P. L., Wilson, S. K., Graham, N. A. J., Cinner, J. E., Bellwood, D. R. et al. (2008). Effects of Climate-Induced Coral Bleaching on Coral-Reef Fishes-Ecological and Economic Consequences. In Oceanography and Marine Biology (pp. 257-302). Boca Raton, FL: CRC Press. https://doi.org/10.1201/9781420065756.ch6

Rael, H., Tommy, N., Watson, S.-A., CA, P. J., Ricardo, B., Simon, H., Jean-Pierre, G. et al. (2020). Near-Future Ocean Warming and Acidification Alter Foraging Behaviour, Locomotion, and Metabolic Rate in a Keystone Marine Mollusc. Scientific Reports, 10, Article No. 5461. https://doi.org/10.1038/s41598-020-62304-4

Richardson, A. J., \& Poloczanska, E. S. (2008). Under-Resourced, under Threat. Washington DC: American Association for the Advancement of Science. https://doi.org/10.1126/science.1156129

Root, T. L., Price, J. T., Hall, K. R., Schneider, S. H., Rosenzweig, C., \& Pounds, J. A. (2003). Fingerprints of Global Warming on Wild Animals and Plants. Nature, 421, 57. https://doi.org/10.1038/nature01333

Rosenzweig, C., Casassa, G., Karoly, D. J., Imeson, A., Liu, C., Menzel, A. et al. (2007). Assessment of Observed Changes and Responses in Natural and Managed Systems.

Ruiz-Navarro, A., Gillingham, P. K., \& Britton, J. R. (2016). Shifts in the Climate Space of Temperate Cyprinid Fishes Due to Climate Change Are Coupled with Altered Body Sizes and Growth Rates. Global Change Biology, 22, 3221-3232. https://doi.org/10.1111/gcb.13230

Smith, D. M., Cusack, S., Colman, A. W., Folland, C. K., Harris, G. R., \& Murphy, J. M. (2007). Improved Surface Temperature Prediction for the Coming Decade from a Global Climate Model. Science, 317, 796-799. https://doi.org/10.1126/science.1139540

Smith, J. (2016). The Effects of Ocean Acidification on Zooplankton: Using Natural $\mathrm{CO}_{2}$ Seeps as Windows into the Future. Plymouth: University of Plymouth.

Spies, I., Gruenthal, K. M., Drinan, D. P., Hollowed, A. B., Stevenson, D. E., Tarpey, C. M. et al. (2020). Genetic Evidence of a Northward Range Expansion in the Eastern Bering Sea Stock of Pacific Cod. Evolutionary Applications, 13, 362-375. https://doi.org/10.1111/eva.12874

Sunday, J. M., Pecl, G. T., Frusher, S., Hobday, A. J., Hill, N., Holbrook, N. J. et al. (2015). Species Traits and Climate Velocity Explain Geographic Range Shifts in an OceanWarming Hotspot. Ecology Letters, 18, 944-953. https://doi.org/10.1111/ele.12474

Van Woesik, R., \& Randall, C. J. (2017). Coral Disease Hotspots in the Caribbean. EcoSphere, 8, e01814. https://doi.org/10.1002/ecs2.1814

Verberk, W. C. E. P., \& Bilton, D. T. (2011). Can Oxygen Set Thermal Limits in an Insect and Drive Gigantism? PLOS ONE, 6, e22610. https://doi.org/10.1371/journal.pone.0022610

Vivekanandan, E. (2006). Impact of Climate Change on Marine Fisheries (pp. 1-4). CMFRI News-Letter No. 112 October-December 2006.

White, B. N. (2018). The Role of Ontogenetic Habitat Shifts on the Parasite Communities of Five South Florida Fishes.

Wiedenmann, J., Cresswell, K., \& Mangel, M. (2008). Temperature-Dependent Growth of 
Antarctic Krill: Predictions for a Changing Climate from a Cohort Model. Marine Ecology Progress Series, 358, 191-202. https://doi.org/10.3354/meps07350

Worm, B., Sandow, M., Oschlies, A., Lotze, H. K., \& Myers, R. A. (2005). Global Patterns of Predator Diversity in the Open Oceans. Science, 309, 1365-1369. https://doi.org/10.1126/science.1113399

Yao, C.-L., \& Somero, G. N. (2014). The Impact of Ocean Warming on Marine Organisms. Chinese Science Bulletin, 59, 468-479. https://doi.org/10.1007/s11434-014-0113-0

Zacharia, P. U. (2017). Impact of Climate Change on Marine Sector (pp. 255-263). 